\title{
Er apostrofen et økologisk instrument?
}

Du står ved busstoppestedet med en kvinde, du ikke kender. Du kan se bussen nærme sig længere nede ad vejen, da hun pludselig henvender sig til dig: "Vejret er godt nok sært i dag!” Du tøver. Hvad mener hun med det? Hentyder hun mon til den globale opvarmning? Eller forsøger hun bare at slå tiden ihjel med lidt uskyldig small talk? "Ja," svarer du, velvidende at dit lidt tvivlende tonefald og den lange tænkepause allerede har gjort situationen noget mere akavet, end den burde have været. Hun ser undrende på dig og siger ikke mere. Nu kommer bussen endelig. I stiger ind, og du sætter dig på behørig afstand af kvinden.

Scenariet er inspireret af Timothy Mortons filosofiske værk Hyperobjects: Philosophy and Ecology after the End of the World. Ifølge Morton er du med din tøven et levende bevis på, at vi har lagt tiden, hvor vi kunne have en uskyldig samtale om vejret, bag os. Det er ikke længere muligt bare at tale om vejret. Den globale opvarmning ånder os i nakken, mens vi snakker: "The presence of global warming looms into the conversation like a shadow, introducing strange gaps." (Morton 2013, 99) Den globale opvarmning er et forstyrrende eller lidt skummelt fænomen, som de færreste bryder sig om at tale om (Morton 2009, 1). Samtidig er klimaændringerne for mange en abstraktion, som er svær at begribe og forholde sig til. Den globale opvarmning er med Mortons ord et hyperobjekt, altså et objekt, som ikke kan røres eller ses, men som er målbart og kan repræsenteres ved hjælp af grafer (Morton 2013, 2-3). De flestes hverdag er ikke direkte påvirket af den globale opvarmning, men man kan "følge med i den" på hjemmesider som f.eks. NASAs "Global Climate Change: Vital Signs of the Planet" (http://climate.nasa.gov/), hvor klimarelaterede ændringer udstilles gennem målinger, grafiske repræsentationer, videoklip mm. Den globale opvarmning og klimakrisen generelt peger på, at "verden", som vi kender den, er forandret (deraf Mortons undertitel), og at mennesket nu kan betragtes som en decideret planetarisk indflydelseskilde - et forhold, der ligger til grund for en ny geologisk æra, Antropocæn. 
Denne artikel udspringer af en interesse for, hvordan litteratur og nærmere bestemt digte kan formidle et $\varnothing$ kologisk tankesæt og hjælpe os med at forholde os til de komplekse problemstillinger, som klimakrisen opstiller. Spørgsmålet er, hvordan litteraturen helt konkret kan være med til at forhandle relationen mellem mennesket og dets omgivelser i lyset af den antropocæne verdensorden - hvordan litterære virkemidler kan forbinde os til alt lige fra Mortons ubegribelige hyperobjekter til mere dagligdags ting. Jeg vil argumentere for, at en figur som den lyriske apostrofe er et eksempel på et virkemiddel, der kan fremme økologisk sensibilitet og bygge bro til de ikke-menneskelige omgivelser. For at understøtte mit argument vil jeg bl.a. inddrage Jane Bennetts Vibrant Matter: A Political Ecology of Things (2010). Bennett er en af flere nutidige teoretikere, som beskæftiger sig med den tingslige verdens handlekraft og politiske indflydelse, og med hvordan en anerkendende tilgang til vores omgivelsers vitalitet kan bane vejen for en mere holdbar levevis. Min artikel tager afsæt i den tese, at disse teoretiske forslag om det ikke-menneskeliges betydningsfuldhed ikke er ny i den lyriske tradition. Lige så længe der har eksisteret digte, er de blevet adresseret til hvem som helst og ikke mindst hvad som helst alt fra russiske ikoner til alger i Stillehavet. I det følgende vil jeg således illustrere, hvordan dette horisontale register for henvendelser, som apostrofen baserer sig på, gør den særligt egnet til at kommunikere abstrakte forestillinger om økologisk sensibilitet og sameksistens på et konkret niveau.

\section{Kunsten at vende sig væk}

Lad os først se nærmere på, hvad den lyriske apostrofe er og gør. Begrebet apostrofe kommer fra det græske apostrophē, som betyder "at vende sig bort" (Fryd 1999, 93). Den romerske retoriklærer Quintilian definerede apostrofen som "the diversion of our speech from the judge" (Quintilian 2006, upag.), altså det at vende sig væk fra dommeren og tiltale f.eks. den anklagede eller retfærdigheden som sådan, men stadig med dommeren som den intenderede modtager. I digtekunsten kan apostrofen siges at følge en lignende bevægelse: det talende subjekt vender ryggen til sin egentlige modtager, læseren, og henvender sig til en fraværende instans, som f.eks. en person, en ting eller et abstrakt fænomen. Horats dedikerede en ode til træet i sin baghave, og den amerikanske digter Kenneth Koch har eksempler på mere abstrakte og humoristiske adressater, bl.a. sit liv som tyveårig, psykoanalyse og det at sige "ja". Her fra digtet "To Psychoanalysis": "I took the Lexington Avenue subway / To arrive at you in your glory days" (Koch 2007, 162).

Koch er et eksempel på en moderne anvendelse af apostrofen, hvor henvendelsen er forholdsvis afdæmpet, men traditionelt set er den markeret med et følelsesbetonet "Åh" eller "O". Percy Bysshe Shelleys "Ode to the West Wind" er nok et af de mest klassiske eksempler på sådan en apostrofe:

$46 \mathrm{O}$ wild West Wind, thou breath of Autumns being, Thou, from whose unseen presence the leaves dead Are driven, like ghosts from an enchanter fleeing, 
Yellow, and black, and pale, and hectic red,

Pestilence-stricken multitudes: O thou,

Who chariotest to their dark wintry bed

I de to første strofer af Shelleys ode støder vi flere gange på det traditionelle udråb "O", der stilistisk signalerer, at vi har at gøre med en digterisk påkaldelse af noget udefrakommende. Det særlige ved apostrofen som trope er, at den i mere eller mindre eksplicit grad gør opmærksom på sin egen kommunikative situation, skriver Jonathan Culler (Culler 1977, 59). "O" er et udtryk for en slags semantisk "tom" sprogbrug, der alluderer til hele den apostrofiske tradition (Culler 2015, 217). Det er en "invocation of invocation" (Culler 1977, 64). Apostrofen udgør en udsigelse, der peger på sig selv som meddelelse og understreger det medie, der formidler den. "O" illustrerer i den forstand en sammensmeltning af medie og budskab, hvor selve henvendelsen står som det centrale i digtets udtryk, og den poetiske begivenhed træder i forgrunden (Culler 2015, 223). Apostrofen søger at give læseren en fornemmelse af, at den kommunikative situation er en begivenhed, der finder sted her og nu. Den bidrager på den måde til det lyriske "nu": "The fundamental characteristic of lyric $[\ldots]$ is not the description and interpretation of a past event but the iterative and iterable performance of an event in the lyric present, in the special 'now' of lyric articulation." (Ibid., 226)

Apostrofer er ret beset henvendelser til det, som ikke er til stede, et fraværende objekt, som dog bliver gjort nærværende i kraft af selve henvendelsens begivenhed: "apostrofen gør det fraværende nærværende, ikke ved at referere dertil, men ved den hændelse, det er at tiltale det fraværende i digtets nu." (Fryd 1999, 53) En lignende pointe finder man hos Barbara Johnson (Johnson 2014, 530):

4 Apostrophe is thus both direct and indirect: based etymologically on the notion of turning aside, of digressing from straight speech, it manipulates the I/thou structure of direct address in an indirect, fictionalized way. The absent, dead, or inanimate entity addressed is thereby made present, animate, and anthropomorphic. Apostrophe is a form of ventriloquism through which the speaker throws voice, life and human form into the addressee, turning its silence into mute responsiveness.

Apostrofen afstedkommer en bevægelse fra stilhed til lydhørhed, bemærker Johnson. Den retter sig mod en entitet, som nødvendigvis er fraværende, men som bliver gjort nærværende i kraft af den apostrofiske gestus. Det er et spændingsfelt mellem fravær og tilstedeværelse, hvor henvendelsens subjekt er en slags bugtaler, der giver liv til objektet. Citatet stammer fra Johnsons artikel "Apostrophe, Animation, and Abortion" (1987). Artiklen er interessant, fordi Johnson her spørger til, hvordan apostrofen og andre figurative sprogformer fungerer i et politisk perspektiv - f.eks. hvordan apostrofen kan tematisere abort: "[C] an the very essence of a political issue $[\ldots]$ hinge on the structure of a figure? Is there any inherent connection between figurative language and questions of life and death, of who will wield and who will receive violence in a given human society?" (Ibid., 529) 
En lignende interesse for apostrofens politiske potentiale er senere blevet taget op af Helena Feder, der læser forskellige romantiske digteres apostrofer i en $ø$ kokritisk optik (ibid. 2002). Ligesom i nærværende artikel har Feder til formål at udforske sammenhængen mellem den økologiske tanke og apostrofen, som hun bruger til at påpege den potentielle forbindelse mellem social og økologisk retfærdighed (Feder 2002, 58). Hun skriver: "Apostrophe makes these connections explicit; apostrophe allows us the poet's sympathetic imagination, the poet's empathy with and love of the world, in an ever present moment of invocation." (Ibid.) I denne artikel lægger jeg mig i forlængelse af Feders pointe om apostrofen som et udtryk for en sympatisk forestillingsevne. Som vi skal se senere, er en analyse af mere moderne versioner af den apostrofiske henvendelse dog med til at illustrere, hvordan den ikke entydigt baserer sig på kærlighed til omverdenen, men er en interesse for omgivelserne, som også rummer andre følelsesregistre såsom pinlighed og skummelhed. Det vender jeg tilbage til. Et vigtigt grundlag for både Feders og undertegnedes analyser er imidlertid, at apostrofen slår bro mellem subjekt og objekt, digt og omverden. Denne pointe kan findes hos Culler, der bemærker, at apostrofen bygger på en antagelse om, at objektet er en lydhør entitet og eksemplificerer denne pointe med den franske romantiker Alphonse de Lamartines metaapostrofe, “Objets inanimés, avez-vous donc une âme?", hvor subjektet spørger de "livløse objekter" direkte, om de har en sjæl (Culler 2015, 240). En stor del af apostrofens økologiske kvaliteter består således i, at den udfordrer vores vanlige forestillinger om den menneskelige agens kontra en passiv omverden.

Ifølge Culler er denne tiltale af objekter, der normalt bliver anset for livløse, traditionelt blevet forbundet med en vis forlegenhed, hvilket bl.a. har medført, at apostrofen har været en overset figur i litteraturkritikken (ibid., 190). Imidlertid er denne forlegenhed så småt ved at forsvinde. I hvert fald er man i nyere teoretiske retninger som nymaterialisme, tingsteori og økokritik på ingen måde bange for at se nærmere på sondringen mellem menneskelig og ikke-menneskelig handlekraft og spørge til, hvordan man kan gentænke forholdet mellem mennesket og dets materielle omgivelser. Et eksempel er Ian Bogosts Alien Phenomenology, or What It's Like to be a Thing, som ud fra et objekt-orienteret standpunkt undersøger, hvordan vi filosofisk sætter os i tingenes sted (Bogost 2012). Hvordan er det at være en ting, et ikke-menneskeligt objekt? Dette er også, som vi vil se, apostrofens interesse. I lyset af disse teorier fremstår ting som aktive entiteter, og i det følgende vil jeg komme ind på flere teoretiske eksempler. Apostrofen peger dog på, at det er en idé, som længe er blevet behandlet i digtekunsten. Digterne, skriver Culler, var her først (Culler 2015, 242):

6f The poets, though, were here first. They have risked embarrassment in addressing things that could not hear in an attempt to give us a world that is perhaps not more intelligible but perhaps more in tune with the passionate feelings, benign, hostile, and ecstatic, that life have inspired. The testing of ideological limits through the multiplication of the figures who are urged to act, to listen, or to respond is part of the work of lyric. 
Igennem tiden har digtekunsten anvendt den apostrofiske henvendelse til at skabe intime kanaler til den ikke-menneskelige verden og ad den vej udforsket, hvad vi kan forstå som livfuldt og betydningsfuldt. I det følgende vil jeg udvide denne pointe og se nærmere på, hvordan apostrofen kan fungere som et økologisk instrument i lyset af forskellige $\varnothing$ kologiske teorier.

\section{Apostrofen og økologisk sensibilitet}

Den chilenske digter Pablo Neruda er et godt eksempel på, hvor bred viften af apostrofens mulige henvendelser er. Neruda har forfattet oder til et par sokker, sørgmodigheden, alger, en farvestrålende lastvogn belæsset med tønder - for nu at nævne et par stykker. Her er begyndelsen på “Ode til sæben” (Neruda 2009, 424):

64 Nærmer jeg

sæben

til mit ansigt

forbløffes jeg

af dens stærke duft:

Jeg ved ikke

hvor du stammer fra,

duft,

fra hvilken provins

du kommer.

Vi ser her, hvordan et velkendt objekt, en håndsæbe og dens duft, pludselig har en overraskende indvirkning på det poetiske subjekt. Det er værd at bide mærke i, at det er forbløffelsen, der fungerer som en slags katalysator for subjektets henvendelse. Senere forekommer endnu en tydelig markering af den apostrofiske vending, hvor subjektet igen vender ryggen til læseren for at tiltale sæben direkte: "Dufter du af løvværk, / af ung kærlighed eller / af fødselsdagskage? Dufter du / af blødende hjerte?" (ibid., 424-425) Sæben sætter noget i gang, den deltager i jeget, som transformerer sin oplevelse af sæben til et følelsesladet, poetisk udtryk. Sæben spiller på den måde ikke en passiv rolle i digtet, men er nærmere kendetegnet ved en form for forbløffende handlekraft.

Bennetts Vibrant Matter (2010) kan hjælpe med en teoretisering af den forbløffelse over sæbens væsen, som finder sted i Nerudas digt. Her argumenterer Bennett for en såkaldt "Thing-power", der beskriver materielle genstandes iboende livfuldhed (Bennett 2010, 3-4). Objekter er ifølge Bennett ikke døde, passive størrelser. Derimod er de vibrerende og kan påvirke subjekter såvel som indgå i konkrete handlingsmønstre. Et eksempel kunne være chips. Chips gør noget ved vores kroppe, som vi ikke har kontrol over. De forhandler med kroppens fordøjelsessystem og påbegynder produktionen af nyt væv: "To eat chips is to enter an assemblage in which the I is not necessarily the most decisive actor" (ibid., 40). Et andet af Bennetts eksempler er elektricitet, som ikke altid følger den rute, vi havde planlagt for den, og en strømafbrydelse er et udtryk for ikke-menneskelig agens, hvor en masse forskel- 
lige aktører deltager i afbrydelsens begivenhed (Bennett 2005). I den forstand er tingene omkring os aktive entiteter, som påvirker og griber ind i de situationer, de indgår i. De har livs- og handlekraft. Bennett betegner således denne tingskraft som "the curious ability of inanimate objects to animate, to act, to produce effects dramatic and subtle" (Bennett 2010, 6).

I sin beskrivelse af fornemmelsen, der har ligget til grund for teorien om tingskraft, citerer Bennett kunstteoretikeren W.J.T. Mitchell: "Things [...] signal the moment when the object becomes the Other, when the sardine can looks back, when the mute idol speaks, when the subject experiences the object as uncanny" (ibid., 3). Oplevelsen af materielle genstandes vitalitet beror i Bennetts udlægning således på bevægelsen fra objekt til det, Mitchell betegner som ting. Er det ikke lige netop dette forhold, som gør sig gældende i Nerudas "Ode til sæben”? Sæben bliver ikke bare betragtet som et passivt objekt, den producerer tværtimod affekt. En stor del af Nerudas digt består i en opremsning af de associationer, sæbens duft genererer i jeget, formuleret i apostrofiske spørgsmål til sæben: "Fra min kusine / eller fra tøjet i baljen / og de stivfrosne hænder / der vaskede det? / Eller fra disse liljer / jeg husker så godt?" (Neruda 2009, 424). Digtet ender med at konkludere, at sæben er alle disse associationer tilsammen, en energifyldt fortætning (ibid., 426):

6 Alt dette

er du,

sæbe, lutter nydelse,

en flygtig duft

der glider forbi

og synker til bunds

i badekarret

som en blind fisk.

Sæben er ikke fastholdt af henvendelsen, den er "flygtig" og glider væk fra jeget. Denne erkendelse minder meget om en lignende tanke i den nyere teoretisk bevægelse, der kaldes spekulativ realisme eller objekt-orienteret ontologi, der har den amerikanske filosof Graham Harman som en fremtrædende skikkelse. Her arbejder man bl.a. ud fra den filosofiske antagelse, at objekter per definition er uudtømmelige, og at de altid trækker sig tilbage ("withdraws") fra vores forståelsesevne (se f.eks. Harman 2002 og Morton 2013). Nerudas afsluttende apostrofe peger på en tilsvarende antagelse: Sæbens væsen kan ikke udtømmes helt, jeget kan kun nærme sig gennem den apostrofiske henvendelse. Ting er i deres natur glatte som en våd håndsæbe; når vi tror, vi har dem i vores hule hånd, smutter de ud af den.

På trods af deres tilbagetrækning, er det stadig meningsfuldt at forsøge at nærme sig de ikke-menneskelige aktører, sådan som jeget i Nerudas ode gør. Det er en form for $\varnothing$ kologisk interesse: "to begin to experience the relationship between persons and other materialities more horizontally, is to take a step toward a more ecological sensibility" (Bennett 2010, 10). Nerudas ode er et eksempel på denne form for $\emptyset k$ kogisk sensibilitet, hvor jeget indgår i en sær intimrelation med sæben og oplever den i øjenhøjde. Forbløffelsen over sæbens karakter fungerer som et startskud for 
en direkte henvendelse til den, hvorved jeget spørger sæben direkte. Sæben har en dimension, som ikke er under subjektets kontrol. Den producerer affekt hos jeget, og den undviger henvendelsens udtømning. Samtidig markerer apostrofen, at jeget ikke ser ned på sæben, men derimod søger at opstille en horisontal relation imellem dem. Den slags relationer kan være med til at etablere en mere holdbar omgang med omverdenen, skriver Bennett: "This sense of a strange and incomplete commonality with the out-side may induce vital materialists to treat nonhumans - animals, plants, earth, even artifacts and commodities - more carefully, more strategically, more ecologically" (ibid., 18).

\section{Den pinlige og den skumle økologi}

Apostrofer baserer sig på henvendelser til mulige og ofte umulige modtagere (Culler 2015, 216), hvilket peger på, at den som figur udøver en form for økologisk sensibilitet over for sine omgivelser, en udforskning af relationer, menneskelige såvel som ikke-menneskelige. Disse relationer er i høj grad præget af intimitet, og som jeg tidligere har været inde på med Culler, indebærer apostrofiske relationer derfor også en risiko for forlegenhed. Denne forlegenhed kommer af, at apostrofen søger at konstituere en ligeværdig eller horisontal relation imellem den talende og henvendelsens genstand, hvorved den snarere end en relation mellem subjekt og objekt opstiller en "relation between subjects", som Culler formulerer det (ibid., 229). I dette afsnit vil jeg se nærmere på dette potentielt pinlige aspekt ved apostrofen - og i forlængelse af det, hvordan apostrofen også kan have en mere uhjemlig, eller hvad man kunne kalde en skummel dimension. Jeg begynder med en analyse af Frank O’Haras digt “Les Étiquettes Jaunes”. Her er digtet i sin fulde længde (O’Hara 2011, 44):

46 Jeg samlede et blad op fra fortovet i dag. Det virker barnligt.

Blad! Du er så stort! Hvordan kan du skifte farve, og så bare falde!

Som om der ikke var noget der hed hæderlighed!

Du er alt for rolig til at svare mig. Jeg er alt for skræmt til at insistere.

Blad! Vær ikke neurotisk som den lille kamæleon. 
Digtet begynder som en fortælling om et jeg, der samler et blad op. I anden strofe taler jeget direkte til bladet, og den apostrofiske gestus finder sted: "Blad! Du er så stort! / Hvordan kan du skifte / farve, og så bare falde!" Ligesom i Nerudas sæbeode, er det forbløffelsen, særheden ved det velkendte, der lader til at være baggrunden for henvendelsen. Jeget fortsætter sin tale til bladet, men må erkende, at bladets svar udebliver: "Du er alt for rolig / til at svare mig. Jeg er alt for / skræmt til at insistere." Hvad er det egentlig, jeget er skræmt over? Er det af ærefrygt over for bladet og dets evne til at skifte farve? Er det et uhyggeligt blad? Måske kan svaret findes i en af digtets første linjer: "Det virker barnligt". Denne formulering peger på, at det har noget at gøre med den apostrofiske forlegenhed, at jeget er skræmt. Via henvendelsen har subjektet skabt en intim relation, som godt kan tænkes at fremstå en smule pinlig - især fordi jeget efter alt at dømme står midt på fortovet og taler til bladet. Der er dog en lille økologisk sejr i, at jeget i digtets sidste strofe bider forlegenheden i sig og står ved sin ikke-menneskelige relation: "Blad!"

Den sidste strofe skiller sig ud fra det øvrige digt: "Blad! Vær ikke neurotisk / som den lille kamæleon." Kommentaren til bladets evne til at skifte farve står resonerende tilbage, hvilende i sin egen særhed. Det er en form for underliggørelse af bladets habitus. Hvis O'Haras digt var et fotografi, kunne man betegne slutlinjerne som dets "punctum" - Roland Barthes' begreb for det, der prikker til os og holder vores opmærksomhed fanget (Barthes 2004, 38). Man kan også sige (med citatet af Mitchell in mente), at det er i denne strofe, at bladet optræder allermest som ting, da det går fra at være et tavst objekt til en "anden", som ser tilbage på jeget. Timothy Morton har sat ord på denne sammenhæng mellem intimitet og særhed: "Far from gradually erasing strangeness, intimacy heightens it. The more we know them, the stranger they become. Intimacy itself is strange" (Morton 2010, 41). Intimitet går hånd i hånd med særhed. Morton hentyder her til sit begreb om "strange strangers", som refererer til de andre livsformer, vi sameksisterer med. Ifølge Morton består den økologiske tanke i at tænke i forbundethed: "The ecological thought imagines a multitude of entangled strange strangers" (ibid., 15). Vi er viklet ind i sære, omsiggribende relationer, siger Mortons økologiske tanke, og det er der ikke nødvendigvis noget romantisk ved. Mortons $ø$ kologiteori kan betragtes som et opgør med vores idylliserede forestilling om naturen, og han betegner den af samme grund som en "dark ecology" (se f.eks. Morton 2009 og Morton 2010).

En af byggeklodserne i Mortons økologiforståelse er Sigmund Freuds teori om det uhjemlige ("das Unheimliche"), dvs. en følelse af uhygge, som opstår i mødet med det, der er velkendt og fremmed på samme tid (Freud 1998, 17). Faktisk, skriver Morton, er Freuds teori om det uhjemlige essentiel for den $\varnothing$ kologiske tanke (Morton 2010, 52). For Freud udspringer den uhjemlige fornemmelse af repetitionen af det velkendte: "Ifølge mine iagttagelser kan der næppe herske tvivl om, at dette moment under visse betingelser og i kombination med bestemte omstændigheder fremkalder en sådan følelse [af uhygge], som desuden minder om hjælpeløsheden i drømmetilstande" (Freud 1998, 37). Det moment, Freud taler om, er momentet af gentagelse. Dobbeltgængeren er af samme grund en nøgleskikkelse i Freuds teori om det uhjemlige, da der er noget uhyggeligt ved fordoblingen af det velkendte (ibid., 36). Lad os se nærmere på de pointer i forhold til John Ashberys digt "Dette værelse" (Ashbery 2002, 29): 
46 Det værelse jeg kom ind i var en drøm om dette værelse.

Alle de fødder på sofaen måtte jo være mine.

Det ovale portræt

af en hund var mig i en ung alder.

Noget flimrer, noget holdes skjult.

Vi fik makaroni til frokost hver dag

undtagen søndag, hvor en lille vagtel overtaltes til

at blive serveret for os. Hvorfor fortæller jeg dig alt det her?

Du er her ikke engang.

I Ashberys digt finder vi flere genkendelsesmotiver, men de optræder hele tiden i en tilstand af usikkerhed eller forvrængning. Det skaber en stemning, som er både familiær og urolig: Jeget er nogenlunde, men alligevel ikke helt sikker på, at fodaftrykkene på sofaen tilhører det; det genkender sit eget portræt, men portrættet forestiller samtidig en hund, på samme tid en repetition og forvrængning af jeget. I det hele taget følger store dele af digtet, hvad man kunne kalde en drømmenes logik. Tingene både er og er ikke, hvad de giver sig ud for: "Noget flimrer, noget holdes skjult." Der er en form for forskudt dobbelteksponering på færde. Værelset, som digtet udspiller sig i, er en drøm om værelset. Med Freuds ord kan man påpege, at digtets stemning og handling "minder om hjælpeløsheden i drømmetilstande". Med andre ord danner digtet ramme for et uhjemligt scenarie.

Den uhjemlige atmosfære i "Dette værelse" understøttes af tematiseringen af fravær og tilstedeværelse. Der er en grad af intimitet på færde i jegets fortælling, som om jeget og det "du", der tales til, er tæt forbundne. Dette gør det endnu mere overraskende, at modtageren faktisk ikke er til stede: "Hvorfor fortæller jeg dig alt det her? / Du er her ikke engang." Jeg vil behandle denne afsluttende henvendelse som digtets apostrofiske gestus, men den er vel at mærke meget forskellig fra de apostrofer, vi tidligere har analyseret, eftersom modtageren af henvendelsen ikke er en konkret figur, men snarere en abstrakt, uigennemskuelig størrelse. Der er imidlertid lydhørhed i den anden ende af henvendelsen, en art ekkoende ikke-svar. Digtets du er ikke til stede, men tildeles tilstedeværelse i kraft af selve henvendelsen, hvor subjektet fungerer som Johnsons apostrofiske bugtaler, der kropsliggør den fraværende. Denne asymmetri er et eksempel på Mortons begreb om "the strange stranger". Hans formulering "These other beings exists, but they don't really exist" (Morton 2010, 94) er en rammende beskrivelse af problemstillingen i Ashberys digt. Bag ved den apostrofiske henvendelse befinder der sig en utydelig dobbeltgængerskikkelse, som hverken er velkendt eller fremmed, men sært velkendt.

De to digte af henholdsvis O'Hara og Ashbery eksemplificerer på den måde de pinlige og skumle konsekvenser af den apostrofiske henvendelse. Man kan med Culler in mente sige, at det er to konsekvenser, apostrofens subjekt risikerer ved at opstille en horisontal, intim relation mellem sig selv og genstanden for henvendelsen, en relation mellem to subjekter. Hvis vi med udgangspunkt i Mortons teori definerer det at tænke økologisk som at tænke i omsiggribende relationer, kan det påpeges, at apostrofens figur understreger to væsentlige aspekter af denne tanke i praksis: De 
pinlige såvel som de mere skumle kontaktflader er komponenter i den økologiske tanke. Vi skal være pinlige, og vi skal være bugtalere, som omfavner sameksistensens skummelhed, hvis vi vil nærme os det ikke menneskelige og tænke mere økologisk.

\section{Mod en poetisk-politisk økologi}

"What is it like to listen to birds in the Anthropocene?" (Whitehouse 2015, 53) Det spørgsmål stiller Andrew Whitehouse i sit studie af fuglesang i den antropocæne tidsalder, hvor mennesket betragtes som en geologisk kraft. Whitehouses studie bygger på forestillingen om, at Antropocæn ud over at være en geologisk tidsalder desuden er en ny fortolkningsramme, der tvinger os til at revurdere menneskets plads i og relation til den ikke-menneskelige verden (ibid., 70). Man kunne med afsæt i Whitehouses spørgsmål spørge, om denne fortolkningsramme også gælder for litteraturen, og hvad det i så fald betyder at læse digte i Antropocæn? Og derudfra, om en specifik poetisk figur som apostrofen kan have et indlejret politisk potentiale i lyset af den antropocæne virkelighed?

Udforskningen af de spørgsmål kan selvsagt tage mange retninger. Grundet de klimatiske forandringer, som præger vores tidsalder, er det dog oplagt at gå i en $\varnothing$ kokritisk retning og reflektere over, hvordan digte og de virkemidler, vi finder i poetiske genrer, kan hjælpe os med at relatere til nutidens økologiske udfordringer. I kølvandet på klimakrisen er økokritikken i de senere år vundet frem som en forskningspraksis, hvor bl.a. litterære genstande analyseres og evalueres i forhold til, hvordan de kan hjælpe os med at forholde os til klimakrisen på en konstruktiv og fremadrettet måde. En af de store økokritiske udfordringer består, som Richard Kerridge har påpeget, i forholdet mellem klimakrisens på den ene side akutte karakter og på den anden side dens abstrakte karakter eller dybde, som gør den svær at engagere sig i (Kerridge 2014, 361). I tråd med diskrepansen mellem akuthed og dybde er de problemstillinger, som Antropocæn rammesætter, i høj grad forbundet med spørgsmålet om skala: Hvad har det enkelte menneske med vores arts planetforandrende effekt at gøre? Hvad er individets aktie i klimakrisen? Timothy Clark har formuleret denne problematik i sin idé "derangements of scale" (Clark 2012, upag.), en forvirrende sammenfletning af forskellige skalaer. Man kan forklare det sådan, at det at forsøge at leve økologisk i henhold til klimakrisen nogenlunde svarer til at finde vej i en fremmed storby ved hjælp af et kort over hele verden (ibid.) - det er to vidt forskellige skalaer, en forvirring mellem det lokale og det globale.

I samme forstand er der ufatteligt langt fra et stykke sæbe eller et blad til den globale opvarmning, hvilket kan få Nerudas og O'Haras apostrofer til at virke nyttesløse i klimakrisens store perspektiv. De har imidlertid den fordel, at de beskæftiger sig med den nære relation mellem det menneskelige og ikke-menneskelige, og på den måde fremstiller de idéen om sameksistens på et konkret og overskueligt niveau. Den apostrofiske henvendelse er som udgangspunkt forankret i det lokale, men som tankefigur er den meget elastisk: Selve bevægelsen, den anerkendende tilgang til det ikke-menneskeliges vitalitet, er i princippet den samme på et lokalt såvel som et globalt plan. Hvis man først kan anerkende et stykke sæbe som en liv- 
fuld genstand, og chips og strømafbrydelser som ting, der kan handle uafhængigt af den menneskelige intention, er det måske nemmere bagefter at anerkende den globale opvarmning som en konkret aktør i verden, der kræver vores politiske opmærksomhed. Den apostrofiske figur tilbyder os et $\emptyset$ kologisk kompas, som vi kan navigere efter på flere skalaer.

I løbet af denne artikel har jeg vist, hvordan apostrofen på forskellige måder udtrykker økologisk sensibilitet og i kraft af sin horisontale henvendelse opstiller en intim kanal til ikke-menneskelige entiteter. Dette peger på et grundlæggende økologisk potentiale i apostrofen, en indbygget anerkendelse af den anden, hvilket er en tankefigur, som gør apostrofen aktuel i den antropocæne tidsalder. Antropocæn understreger måske mere end nogensinde før, at vi er forbundet med en masse af Mortons "strange strangers", og at vi er tvunget til at navigere i informationer om entiteter, som er abstrakte for os, f.eks. den globale opvarmning. Af samme grund afføder Antropocæn et stigende behov for at konkretisere den andethed, som vi ikke nødvendigvis kan se eller røre, men som ikke desto mindre øver indflydelse på os og planeten. Økologisk sensibilitet drejer sig ikke længere om blot at opbygge relationer til naturen - det drejer sig også om at anerkende sæbers eller strømafbrydelsers handlekraft og ikke mindst det ubegribeliges handlekraft. Som Kate Wright har bemærket, byder Antropocæn på relationer, som vi slet ikke er vant til at engagere os i: "Becoming-with nonhumans, and appreciating their capacity for meaning-making and worlding, may enhance our ability to respond to the disturbing and amorphous becoming-withs of the Anthropocene - more-than-(but including)-human assemblages like superstorms, acidifying oceans, and antibiotic resistant bacteria" (Wright 2014, 280).

Det er ikke usandsynligt, at en figur som apostrofen træner vores $\varnothing$ kologiske forestillingsevne og hjælper til at begribe og relatere til disse mere abstrakte og foruroligende fænomener. At den ændrer noget på et erkendelsesmæssigt plan. Vi skal omfavne det pinlige såvel som det skumle, påpeger apostrofen. Og måske er der endda en chance for, at der snart vil blive skrevet apostrofer til Wrights antropocæne entiteter - superstorme, forsurede have, multiresistente bakterier? Uanset hvad er der meget at hente i de apostrofer, som allerede findes. Tag f.eks. John Ashberys digt, som blev behandlet i det forrige afsnit, og som henvender sig til en uigennemskuelig skikkelse: "Hvorfor fortæller jeg dig alt det her? / Du er her ikke engang." Et du, som ikke er til stede, men som så alligevel er - i kraft af henvendelsens begivenhed. Læst ilyset af Antropocæn får disse linjer en hel ny betydning. Nu fremstår de ikke blot som en henvendelse til en fraværende person, men konkretiserer i nærmest uhyggelig grad vores relation til de antropocæne fænomener.

Culler skriver om apostrofen, at den som figur er rodfæstet i den poetiske diskurs, og at den ikke er særlig almindelig i andre offentlige diskurstyper (Culler 2015, 216). Det er svært at være uenig i, og det er nok heller ikke så sandsynligt, at fremtidens politikere vil vende ryggen til deres publikum for at tale direkte til den globale opvarmning eller den forhøjede udledning af kvælstof i vandkilderne. Det udelukker dog ikke, at litteraturen kan fungere som et rum for den slags sensible relationer, og at vi kan bruge den poetiske diskurs som inspirationskilde i et kulturelt tankesæt. Theodor Adorno har pointeret, at vi ofte forfalder til at tænke po- 
esien som en individuel oplevelse og som noget, der er afsondret fra og endda står i modsætning til samfundet (Adorno 2014, 340). Adorno argumenterer imod denne skarpe sondring mellem poesi og samfund, og på samme måde kan en del af det økokritiske projekt siges at bestå i at trække pointer fra det litterære erkendelsesrum ind i det offentlige rum. Feder peger ligeledes på poesiens politiske potentiale med henvisning til Shelleys idé om poesien som en form for vækstlag, der danner grobund for ændringer i hele samfundets tankesystem (Feder 2002, 57). Litteraturen kan på den måde være med til at understøtte det, Bennett betegner som politisk $ø$ kologi:

16 I think of political ecology as the art of persuading people, at the levels of perception and sensibility as well as reason, that they are Earthlings. Earthlings as well as women, men, Americans, Republicans, et cetera. Nudging people to feel more of the rich complexity of material life, to think of nature not as something out there but as a set of interacting forces, flows, and entities at work inside our bodies as they also form various kinds of links across bodies. (Bennett 2015, 153)

Bennetts teori baner vejen for at spørge til, hvordan det hele ville se ud, hvis vi begyndte at tage vores omgivelser alvorligt? Hvis vi indtog en mere anerkendende position i forhold til andre, ikke-menneskelige aktører og inddrog dem i vores politiske beslutningsprocesser?

Et led i denne proces, skriver Bennett, er at slippe af med vores antropocentriske idé om mennesket som hævet over resten af verden, og her kan besjælingen måske være en hjælpende hånd: "If a green materialism requires of us a more refined sensitivity to the outside-that-is-inside-too, then maybe a bit of anthropomorphizing will prove valuable." (Bennett 2010, 120) Bennett bemærker selv de ideologiske, antropocentriske faldgruber, som ofte går hånd i hånd med besjælingens figur, men påpeger dertil, at besjæling faktisk modarbejder antropocentrismen: "Maybe it is worth running the risks associated with anthropomorphizing (superstition, the divinization of nature, romanticism) because it, oddly enough, works against anthropocentrism: a chord is struck between person and thing, and I am no longer above or outside a nonhuman 'environment'." Besjælingen eller i dette tilfælde apostrofen er med til skabe familiære forbindelser mellem menneske og ting og påpeger, at mennesket ikke står uden for det ikke-menneskelige, men at de to ting er viklet ind i hinanden.

På den måde er apostrofen et økologisk instrument, der formidler besjælinger af det ikke-menneskelige og dermed økologisk sensibilitet, men samtidig nuancerer vores forestilling om at besjæle det ikke-menneskelige. Der er ikke nødvendigvis noget romantisk over apostrofen - som vi har set, kan den både fremkalde forlegenhed og forurolige fornemmelser, og den henvender sig til blade såvel som sæbestykker. Apostrofen illustrerer, hvordan poesien kan være med til at forhandle, hvordan vi tænker menneskets relationer til det ikke-menneskelige i den antropocæne eller den chthulucæne tidsalder, som Donna Haraway har benævnt den (Haraway 2016). Vi lever i en tid, hvor vi måske mere end nogensinde før har brug for poetiske tankefigurer som apostrofen, som formidler en sympatiserende og deltagende tilgang 
til de ikke-menneskelige entiteter, som vi er forbundet med på kryds og tværs. Som et slogan for denne tidsalder har Haraway foreslået det sameksistensbetingede udsagn “Make Kin Not Babies!" (Haraway 2015, 161). Hvis jeg på baggrund af mit eget studie selv skulle foreslå et slogan, ville det nok være: Vær pinlig! Vær skummel! Lav apostrofer!

\section{Noter}

I Der er visse teoretiske forskelle på Bennetts materialisme og Harmans og Mortons objekt-orienteret ontologi. Jeg vil dog ikke gå dybere ind i disse parters uenigheder her, da det peger i en anden retning end mit analytiske fokus, men for interesserede fremlægger Bennett bl.a. sin kritik af objekt-orienteret ontologi i artiklen "Systems and Things: A Response to Graham Harman and Timothy Morton." (2012)

\section{Litteratur}

Adorno, Theodor W. (2014): "On Lyric Poetry and Society", Virginia Jackson, Yopie Prince (red.): The Lyric Theory Reader: A Critical Anthology, Baltimore: Johns Hopkins University Press, s. 339-350. Ashbery, John (2002): Søvnens landsby, København: Basilisk.

Barthes, Roland (2004): Det lyse kammer - Bemærkninger om fotografiet, København: Gyldendals Bogklubber.

Bennett, Jane (2004): “The Force of Things: Steps Toward an Ecology of Matter”, Political Theory 32.3, s. 347-372.

Bennett, Jane (2005): “The Agency of Assemblages and the North American Blackout". Public Culture 17.3, s. 445-465.

Bennett, Jane (2010): Vibrant Matter: A Political Ecology of Things, Durham: Duke University Press. Bennet, Jane (2015): "Eco-sensibilities: An Interview with Jane Bennett", Interview v. Janell Watson, Minnesota Review 81, s. 147-158.

Bogost, Ian (2012): Alien Phenomenology, Or What It's Like to Be a Thing, Minneapolis: University of Minnesota Press.

Clark, Timothy (2012): "Scale: Derangements of Scale", Telemorphosis: Theory in the Era of Climate Change 1, upag.

Culler, Jonathan (1977): "Apostrophe”, Diacritics 7.4, s. 59-69.

Culler, Jonathan (2015): Theory of the Lyric, Cambridge: Harvard University Press.

Feder, Helena. 2002. "Ecocriticism, New Historicism, and Romantic Apostrophe", Steven Rosendale (red.): The Greening of Literary Scholarship: Literature, Theory, and the Environment, Iowa City: University of Iowa Press, s. 42-58.

Freud, Sigmund (1998): Det uhyggelige, København: Politisk revy.

Fryd, Anette (1999): Ekfraser: Gunnar Ekelöfs billedbeskrivende digte, København: Museum Tusculanums Forlag.

Haraway, Donna (2015): "Anthropocene, Capitalocene, Plantationocene, Chthulucene: Making Kin", Environmental Humanities 6, s. 159-165.

Haraway, Donna (2016): Staying with the Trouble: Making Kin in the Chthulucene, Durham: Duke University Press.

Johnson, Barbara. 2014. "Apostrophe, Animation, and Abortion", Virginia Jackson, Yopie Prince 
(red.): The Lyric Theory Reader: A Critical Anthology, Baltimore: Johns Hopkins University Press. Kerridge, Richard (2014): "Ecocritical Approaches to Literary Form and Genre: Urgency, Depth, Provisionality, Temporality", Greg Garrard (red.): The Oxford Handbook of Ecocriticism, New York: Oxford University Press.

Koch, Kenneth (2007): Selected poems, Library of America.

Morton, Timothy (2009): Ecology without Nature: Rethinking Environmental Aesthetics, Cambridge: Harvard University Press.

Morton, Timothy (2010): The Ecological Thought, Cambridge: Harvard University Press.

Morton, Timothy (2013): Hyperobjects: Philosophy and Ecology after the End of the World, London: University of Minnesota Press.

Neruda, Pablo (2009): Elementære oder, København: Forlaget Sohn.

O’Hara, Frank (2011): Til minde om mine følelser, København: Basilisk.

Quintilian (2006): Institutes of Oratory, online på http://rhetoric.eserver.org/quintilian/ (tilgået d. 15-01-2017).

Shelley, Percy Bysshe (1907): Lyrics and Shorter Poems, Edinburgh: Turnbull and Spears.

Whitehouse, Andrew (2015): "Listening to Birds in the Anthropocene: The Anxious Semiotics of Sound in a Human-dominated World", Environmental Humanities 6, s. 53-71.

Wright, Kate (2014): "Becoming-with (Living Lexicon for the Environmental Humanities)", Environmental Humanities 5, s. 277-281. 